\title{
Fluoroquinolone resistance: relation between drug use and evolution of resistance in some Units of the "San Bassiano" hospital from 2007 to 2008
}

\author{
Claudia Mascotto, Dina Bonini,Alessandra Dinale, Maria Frizzo, Gilberto Lorenzin, Elio Manni, Michela Pozza, \\ Dario Cesco, Maria Teresa Guidi \\ SS di Microbiologia ULSS 3 Bassano del Grappa (VI)
}

Key words: ciprofloxacin, levofloxacin,fluoroquinolone-resistance

Comparazione tra consumo dei fluorochinoloni e loro resistenza in alcuni reparti dell'ospedale S. Bassiano tra il 2007 e il 2008

\section{SUMMARY}

There is substantial evidence that the overuse of antibiotics is a major cause for the emergence in antimicrobial resistance.

This study analyzes the evolution of antimicrobial resistance to ciprofloxacin and levofloxacin from 2007 to 2008 in some Units of the "San Bassiano" hospital and compares this evolution among the consumption of the same antibiotics.

The study involved the collection of all first isolates in blood, urine and transtracheal samples between 2007 and 2008 ; three microorganisms were chosen: Staphylococcus aureus, Escherichia coli and Pseudomonas aeruginosa. Microorganisms investigations concerned Geriatrics, Medicine, Surgery and Intensive Care Unit (ICU) with 48, 48, 44 and 10 beds respectively.

Identification and antimicrobial susceptibility testing was performed using the Phoenix automated system (Becton Dickinson). If the ciprofloxacin susceptibility was (S) and levofloxacin susceptibility was (I/R) antimicrobial susceptibility was confirmed by the E-Test method (bioMérieux) on Muller Hilton agar and cell density of 0.5 MacFarland.

Control strains were E. Coli ATCC 25922, P. aeruginosa ATCC 27853 and S. aureus ATCC 292I 3.

The antibiotics consumed in the hospital between January 2007 and December 2008 were transformed into Defined Daily Dose (DDD), which corresponds to the quantity of antibiotics consumed by a patient in $24 \mathrm{~h}$.

Ciprofloxacin and levofloxacin demonstrated a similar pattern of increasing resistance in some units between 2007 and 2008. Fluoroquinolone resistance increase for E. coli, varies from 10\% in Geriatrics to I5\% in ICU, for S. aureus varies from I5\% in Medicine Unit to $5 \%$ in ICU. P. aeruginosa maintained the same percentage of resistance from 2007 to 2008 , but there was a significantly increase of strains with intermediate sensitivity (I) up to $30 \%$.

The consumption of Ciprofloxacin didn't increase in any of the units and in some case decreased.

The consumption of levofloxacin increased in every units and particularly in ICU it raised from 5100 ev doses in 2007 to 6480 in 2008 and from 0 to 300 doses os (DDD).

The increased consumption of levofloxacin in 2008 in ICU could explain the increased of Pseudomonas aeruginosa strains with intermediate sensitivity (I).

Abbiamo valutato la correlazione tra consumo e ridotta sensibilità a ciprofloxacina e levofloxacina in alcuni reparti dell'Ospedale S. Bassiano tra il 2007 e il 2008.

Questo studio è iniziato dall'osservazione del seguente dato “anomalo"che è stato trovato nell'esecuzione dell'antibiogramma di $P$. aeruginosa nel reparto di Rianimazione.

Due fluorochinoloni di classe omogenea hanno dato i seguenti risultati: Ciprofloxacina $S$ (range secondo CLSI $\mathrm{S} \geq 1, \mathrm{I} 2, \mathrm{R} \geq 4 \mu \mathrm{g} / \mathrm{ml}$ ) e Levofloxacina I (range secondo CLSI $\mathrm{S} \leq 2, \mathrm{I} 4, \mathrm{R} \geq 8 \mu \mathrm{g} / \mathrm{ml})$. Il dato che è stato confermato dal metodo E-Test ${ }^{\boxplus}$ (bioMérieux) ha stimolato una verifica anche in altri reparti e con altri microrganismi.

I reparti esaminati sono stati Geriatria, Chirurgia, Medicina e Rianimazione con 48, 44, 48,10 posti letto rispettivamente. Il consumo dei farmaci è stato misurato come Dose Die posto letto (DDD). I ceppi sono stati isolati da: emocolture, urinocolture e aspirati transtracheali. I microrganismi considerati sono stati: Staphylococcus aureus, Escherichia coli, e P. aeruginosa. L'identificazione dei ceppi e gli antibiogrammi sono stati eseguiti usando il sistema automatico Phoenix ( Becton Dickinson). In caso di ciprofloxacina=S e levofloxacina $=\mathrm{R} / \mathrm{I}$ è stato utilizzato il metodo E-test (bioMérieux) utilizzando il terreno Muller Hinton e con un inoculum del batterio con una torbidità $0.5 \mathrm{MF}$. Come controllo sono stati utilizzati i seguenti ceppi: E. coli ATCC 25922, P. aeruginosa ATCC 27853 e S. aureus ATCC 29213.

Ciprofloxacina e levofloxacina hanno dimostrato un andamento simile con resistenza sovrapponibile ed in aumento nel 2008 in alcuni reparti, per E.coli in geriatria 10\%, del 15\% in rianimazione, per $S$. aureus del 15\% in medicina e del 5\% in rianimazione. $P$. aeruginosa ha mantenuto la resistenza del 2007 anche nel 2008 dimostrando però un aumento rilevante dei ceppi a sensibilità intermedia (ceppi I) che rispetto al 2007 sono aumentati del 30\% (Figura I). In dettaglio E. coli $e S$. aureus dimostrano un aumento di resistenza simile sia per ciprofloxacina che levofloxacina in Geriatria, Medicina e Rianimazione. La resistenza per ciprofloxacina di P. aeruginosa in Geriatria nel 2008 concordava con il 2007.

In Medicina e Rianimazione c'è stata una diminuzione della resistenza per Levofloxacina nel 2008 rispetto al 2007 ed è stato rilevato un aumento dei ceppi a ridotta sensibilità (I) in Rianimazione.

Il fattore che può giustificare l'aumento di resistenza dei microrganismi potrebbe essere un aumento del consumo di antibiotici in ospedale per (3):

- Aumentato uso di profilassi antibiotica

- Aumentato uso di terapia antimicrobica per infezioni polimicrobiche

- Aumentato uso di antibiotici per area geografica

- Terapia inappropriata

Abbiamo verificato l'ipotesi con i consumi calcolati in farmacia in DDD posti letto (Figura II) Considerando il consumo della ciprofloxacina nei vari reparti non si notano variazioni di rilievo anzi si nota in generale un calo nel consumo. Per la levofloxacina l'aumento è costante in tre reparti mentre in Rianimazione si passa da 5100 dosi ev del 2007 a 6480 del 2008 e da 0 a 300 dosi per os (DDD) (1).

L'aumento dei consumi di antibiotico potrebbe giustificare la diminuzione della sensibilità a levofloxacina in Rianimazione nel 2008. Da qui si evince l'importanza del-

\section{Corresponding author: Maria Teresa Guidi}

SS di Microbiologia Ospedale S. Bassiano, Via dei lotti, 40

Tel: 042488864l

E-mail: mariateresa.guidi@aslbassano.it 
l'uso prudente degli antibiotici che deve essere strettamente legato alla sorveglianza continua dell'epidemiologia locale poiché i batteri continuano a sviluppare resistenza sia per mutazione che per scambio di materiale genetico quando sono sottoposti a una pressione selettiva dovuta all'uso di antibiotici (2).

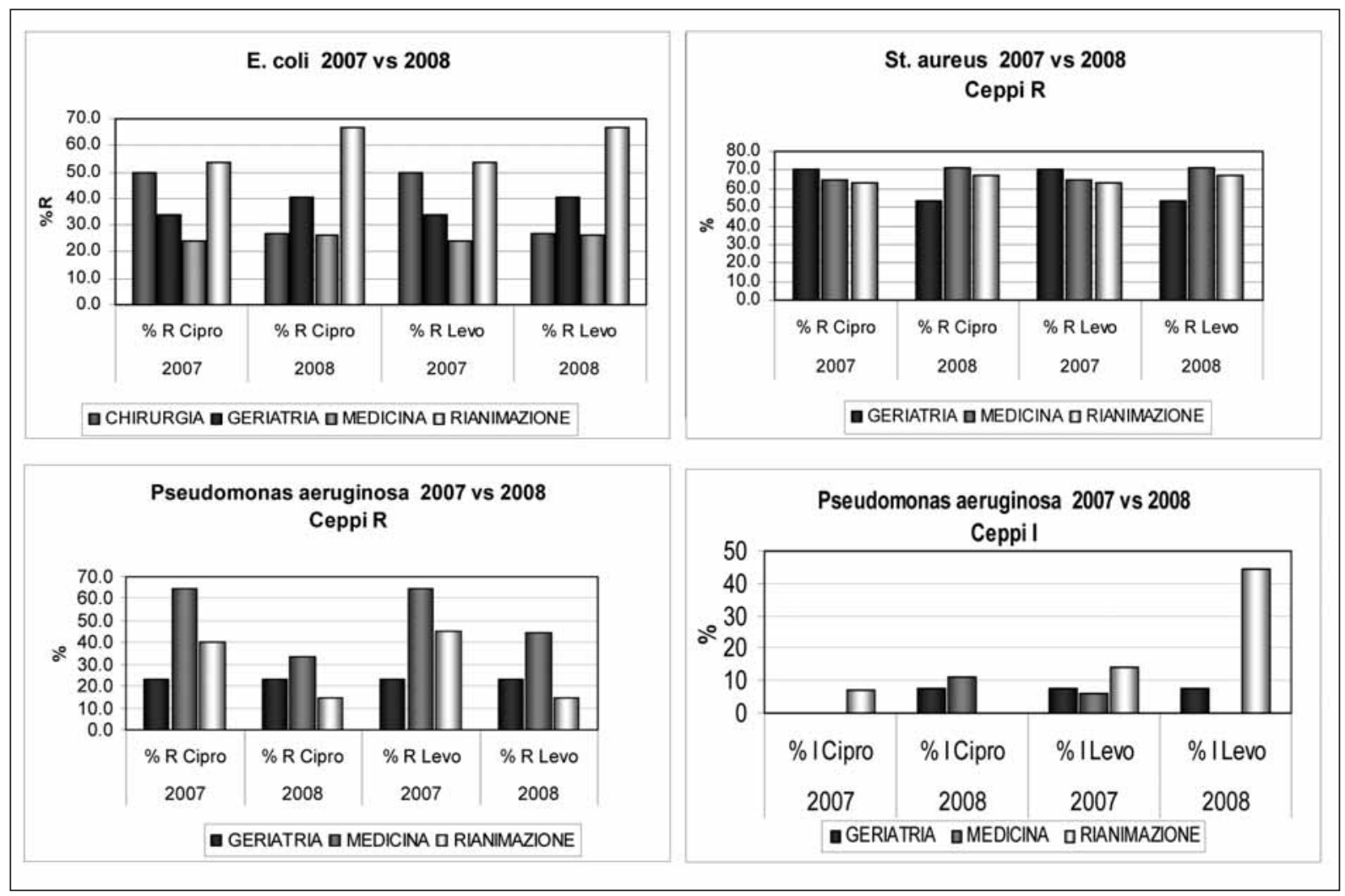

Figura I. Evoluzione della resistenza ai fluorochinoloni nei reparti considerati.

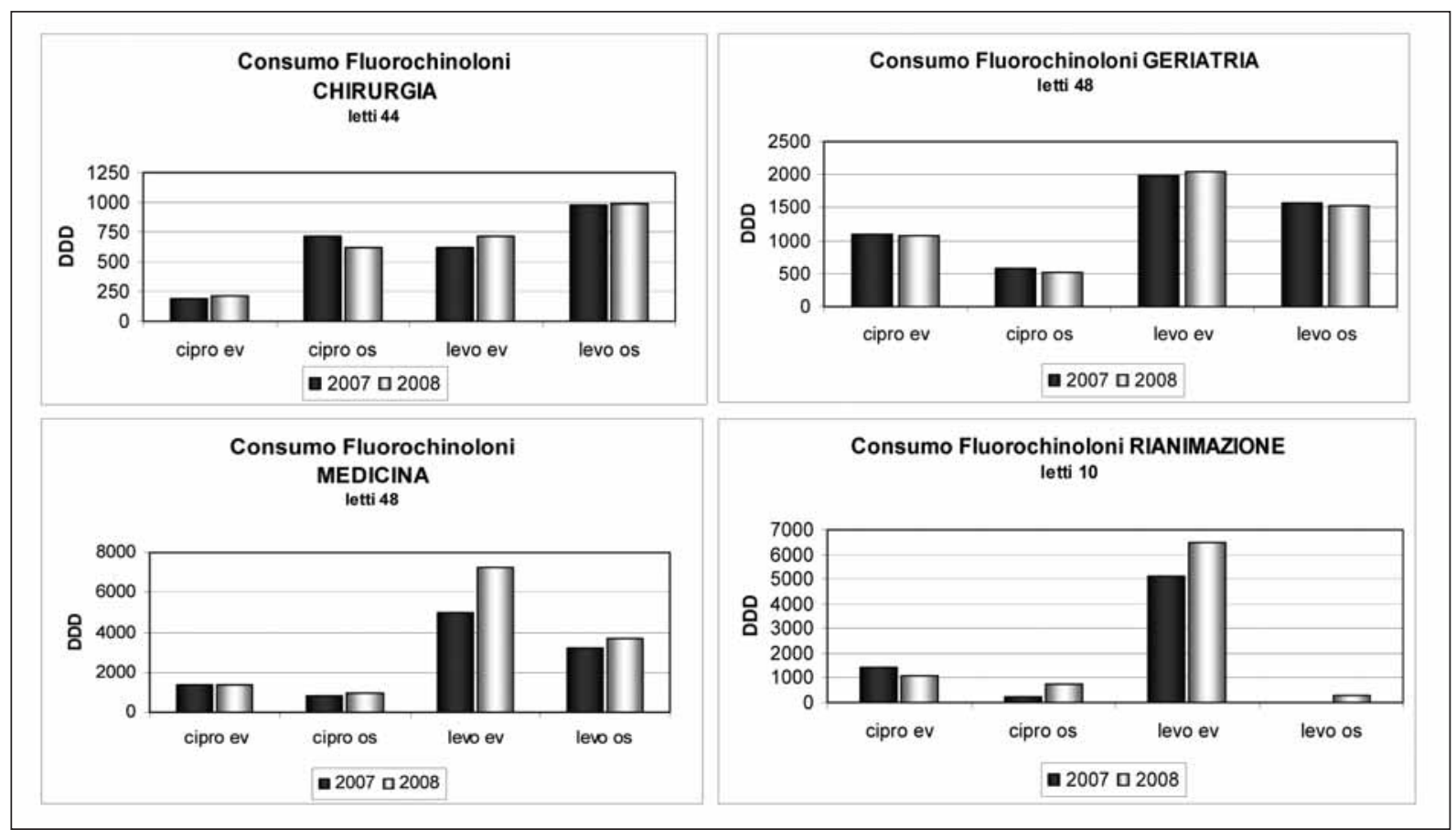

Figura II. Consumo di fluorochinoloni nei vari reparti espresso come DDD.

\section{BIBLIOGRAFIA}

1. Neuhauser MM, Weinstein RA, Rydman R, Danziger LH, Karam G, Quinn JP. Antibiotic resistance among Gram-negative bacilli in US. Intensive care units: implications for fluoroquinolone use. JAMA 2003; 289: 885-8.
2. Paterson DL. Impact of antibiotic resistance in Gram-negative bacilli on empirical and definitive antibiotic therapy. Clin Infect Dis 2008; 47 (suppl 1): S14-20.

3. Tenover FC. Mechanisms of antimicrobial resistance in bacteria. Am J Med 2006; 119 (6A): S3-10. 